\title{
Progression of Body Related Viruses in Human: A Review
}

\author{
Neha Rauniyar*, Deepa Srivastava \\ Department of Botany, D.D.U Gorakhpur University, India
}

Received December 16, 2020; Revised April 22, 2021; Accepted May 10, 2021

\section{Cite This Paper in the following Citation Styles}

(a): [1] Neha Rauniyar, Deepa Srivastava , "Progression of Body Related Viruses in Human: A Review," Immunology and Infectious Diseases, Vol. 9, No. 1, pp. 1 - 10, 2021. DOI: 10.13189/iid.2021.090101.

(b): Neha Rauniyar, Deepa Srivastava (2021). Progression of Body Related Viruses in Human: A Review. Immunology and Infectious Diseases, 9(1), 1 - 10. DOI: 10.13189/iid.2021.090101.

Copyright $\bigcirc 2021$ by authors, all rights reserved. Authors agree that this article remains permanently open access under the terms of the Creative Commons Attribution License 4.0 International License

\begin{abstract}
Human health has been drastically affected due to the emergence of many new and deadly viral infections and also the older that persists, despite much wonderful progress in the area of Biomedical sciences. Some of the best examples which could be cited here is the newly evolving Corona virus (Covid-19) or the virus of 21st century and other several viruses which have been already evolved disturbing the existence of human kind such as Zika virus, Dengue virus [4]. Chikungunya virus, Influenza A virus, SARS, MERS which are known to be transferred in mankind through many arthropods, some animals and several other methods of communication, for this the better understanding of the host pathogen association and relationship with its environment is necessary for the vector control methods which would be used for the prevention of these arboreal infections and this has been proved to be effective in many aspects of controlling the effect of the virus. The main cause of evolution of such pathogenic viruses can be any among some of these such as changing climatic conditions, poor sanitization, increase in population rapidly, rampant construction, uncooked meats etc., and many new evolving anthropophilic vectors which transfer such diseases in humans. Many recent researches have been reported which have shown the immense effort of Medical sciences and scientist to cure various deadly diseases such as HIV, Hepatitis, Chikungunya etc. and to some extent these viruses have been overcome but the nature of viruses is unpredictable and could re-emerge any time in the history which would hamper the control and preventive measures.
\end{abstract}

Keywords Acyclovir, Corona Virus, Dengue Virus,
HIV, Influenza Virus, Papilloma Virus, Valacyclovir, Zika Virus

\section{Introduction}

The advancement of mankind from early man to modern man is a great achievement in itself, but along with the transformation of human many other positive and negative interactions related to humans have also evolved such as its environment, human lifestyle, way of sustenance, and various diseases and its disease-causing pathogens which limits the activity of humans and its functioning system i.e. its immune.

As the progress in the human has occurred over time along with its new techniques and technologies such as the increase in number, density etc. along with which evolved certain number of diseases and its pathogens. The evidence of these pathogens, pathogenic diseases and all about human body has been studied by various researchers since pre-historic times which gives us the clear details about the development of human body over times along with its environment but more or less it has also provided us the detail of Association and interaction of viruses and many other pathogens along with their resistant evolution and long lasting effect.

Dated back since the evolution of Tobacco mosaic virus (1892) to the evolution of Foot and mouth disease virus (1898) and now the virus of new world i.e. Corona virus (2020), it was Yellow fever virus (1901) which was first obtained in filtered form and from then the study of viruses 
became a bit easier and with evolution of techniques with times we developed several vaccines and antibiotics related to evolving viruses and now till date (21st century) the viruses have become the most highly evolved pathogen in much newer and efficient forms, Covid-19 can be cited as one of the examples, and many will keep on evolving along with the passage of time and with the level of human and environment evolution, being the rule of nature. A report suggests that about 2/3rd of the pathogens evolving are mainly the viruses. As the viruses are the highly evolved pathogen from time immemorial causing from simple cold and cough to a deadly Corona disease and many much to be evolved in near future.

This Review paper deals with an approach to combine all the viruses attacking the human body and their diversity, the level of harm they could do to body and their distribution in India level and around the world. Through this review we will be able to discover how the viruses have evolved from time to time in new form all over the body of human. In some aspect we also see how one type of virus affects different parts of the body or sometimes how deadly different virus effect the people of different age groups and what harm do they cause to our immune in different ways. We see in different studies that maximum numbers of the viruses have been reported on the genital region of the body either external or internal but only some are harmful in very severe way and some only persist in the genital area but do not cause much harm or cause no harm to the body. Many papers have been reviewed to bring out all the viruses related to human body, their symptoms, prevention, treatment and distribution all over. Fig 1demonstrates how the viruses evolved and spread over the wide area.

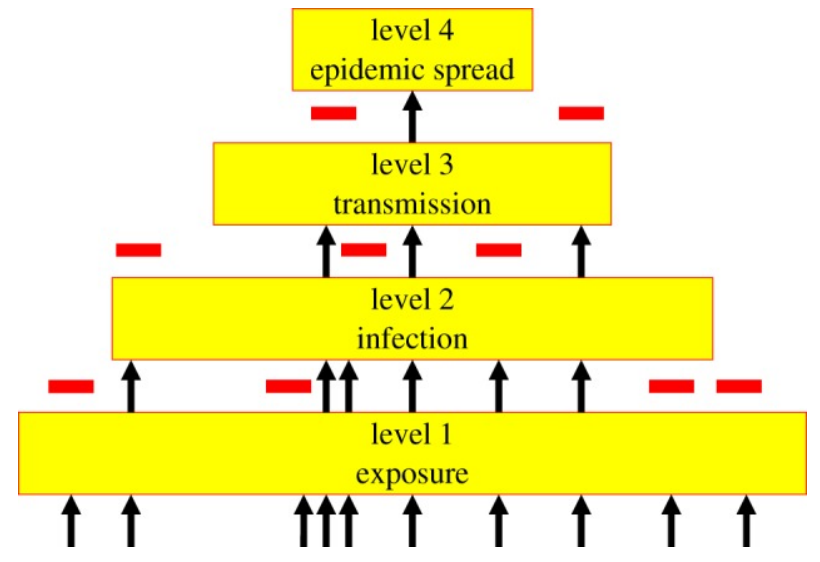

Figure 1. How novel virus evolve: Pathogen pyramid [14]

\section{Detailed Virus Study}

\section{Dengue virus [7].}

Family- Flaviviridae

Genetic structure- single stranded positive RNA virus.
Body part infected- Hairs.

Spread by - Aedes egyptii.

\section{Symptoms-}

- Shedding of scalp hair which increases with high frequency abnormally either through direct infection or by killing the cells of hair follicle.

- This virus may also show interference with the normal hair cycle through some mediators like cytokines.

- Certain other Cytopathic and Molecular changes.

\section{Techniques used for the detection of Virus-}

$$
\begin{aligned}
& \text { - Cell viability Assay } \\
& \text { - } \text { Immunofluorescence Assay } \\
& \text { - } \text { Western blot Analysis. }
\end{aligned}
$$

\section{Medications useful for treatment-}

- Use of Giloy strengthens the immune and protects one's body from the virus.

- Use of Papaya leaves reduces the symptoms of the virus infecting the hair papilla.

- Dried root of Golden seal is used in eradicating the symptoms of Dengue Virus.

Topographical spread of the virus - This virus is mainly endemic and is mainly known to occur in tropical area of Urban population, being less frequent to subtropical regions and very rare in the temperate region in cities.

\section{Cox Sackie virus-}

Family- Picornaviridae

Genetic structure- Single positive strand RNA virus.

Body part infected- Hand, Foot and Mouth disease.

Spread by- Saliva, Nasal and throat discharge, stool, Respiratory droplet etc.

\section{Symptoms-}

Painful, red blisters or lesions on the tongue gums which are without itching sometimes on palms, soles and buttocks.

- Loss of hunger.

\section{Techniques used for the detection of virus-}

- Mac ELISA

\section{Medication required-}

- Uptake of large amount of fluids.

- Maintain good hygiene. 
- Wash hand carefully and regularly.

Geographical distribution of the virus- The virus was mainly reported from United states first report being from New York. Others being Connecticut, Ohio, Kentucky and Philippines.

\section{Herpes Simplex Virus (i or ii) [10,17].}

Family- Herpesviridae

Genetic structure- large, double stranded, Linear DNA.

- Body part infected- Fingertip.

Spread by- from infected person. Symptoms-

- Often looks like Felon which causes Itching or burning sensation due to swelling and Redness.

- One or many exposed wounds occur in the area caused by whitlow and often occur in cluster.

- The first symptom is basically observed after 2-20 days of being exposed to herpes simplex virus [9].

- Whitlow often reappears as the kind of primary infections in the same area as once infected. If untreated whitlow may get converted into a kind of super infectious condition called Herpetic encephalitis (Brain infection).

\section{Technique used for detection of virus-}

- Viral culture invitro

- Serological tests

- Direct immunofluorescence assays

- Light microscopy

\section{Medication required-}

- Oral Acyclovir
- Valacyclovir

Topographical spread of the virus- Major affected regions of the world are America, Africa, Eastern Mediterranean regions, Europe, South east Asia, Western Pacific regions etc.

- Body part infected- Face, nose, Lips and ears.

Spread by- The primary presentation of the Herpes simplex virus is Gingivostomatitis which mainly infects Young children.

\section{Symptoms-}

- There is the sensation of prodromal pain, burning tingling before the emergence of vesicular lesions.

- The lesions can be seen in any area such as face, nose, lips which are less severe.

- Vesicles near mandibular lip and outside of the oral cavity and also Aphthous ulcers.

\section{Technique used for detection of virus-}

- Viral culture test is done for knowing the virus.

- Polymerase chain reaction.

- Tzanck tests.

\section{Medication required-}

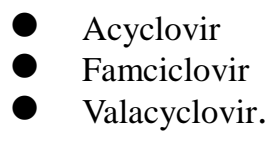

Topographical spread of the virus - Major affected zones in our globe are America, Africa, Eastern Mediterranean regions, Europe, South east Asia, Western Pacific regions etc. Fig: 2 Demonstrates the working of viruses mainly the Flu-virus, Retro virus. 


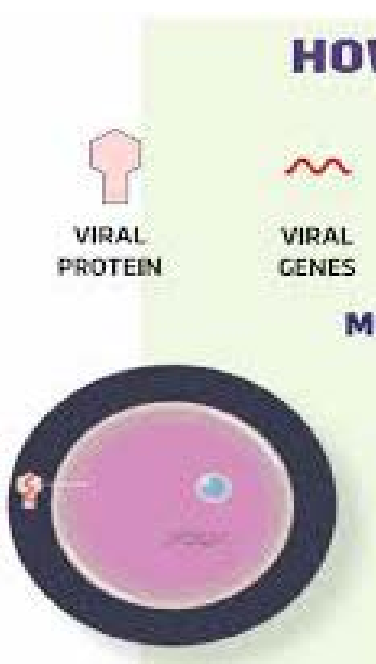

INFECTION

First of all, the virus infects a host cell. It protective protein caat brealks down and the virus releases its genes.

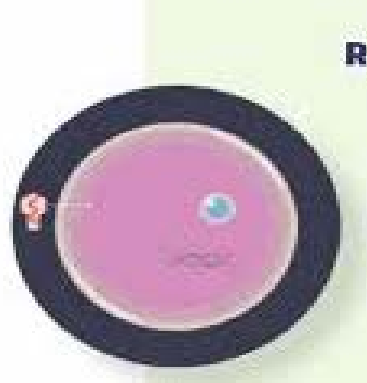

INFECTION

The virus infects a host cell. Its protein coat is braken down and the viral genes (in the form of a DNA-like molecule called RNA) are released into the cell.
HOW VIRUSES WORK
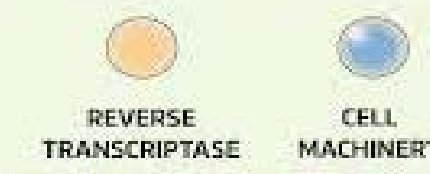

CELL. MACHINERY

MOST VIRUSES (EC. FLU)

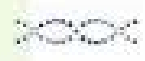

HOST CELL DNA

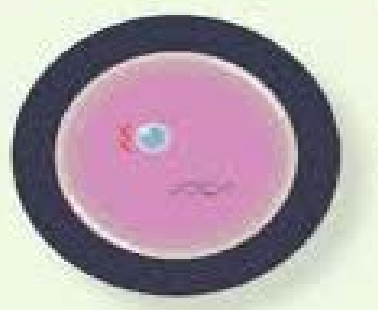

HIJACK!

The virus then takes over the cell machinery that makes genes and prateins. The virus forces it to copy its own genes and make viral proteins.

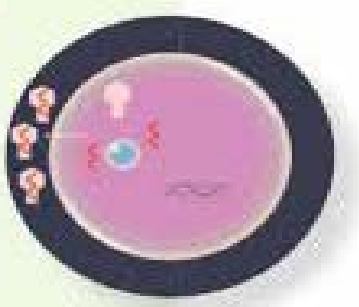

DUPLICATION

New viruses will be assembled inside the host cell. Eventually, they will break out and go in search of new hosts to infect.

\section{RETROVIRUSES (EG. HIV)}

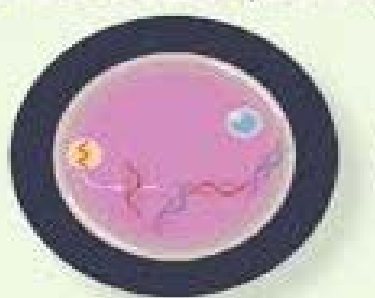

INSERTION

In the cell, the viral RNA uses an enzyme called reverse transcriptase to convert its RNA into DNA, which it inserts into the hast's genetic material.

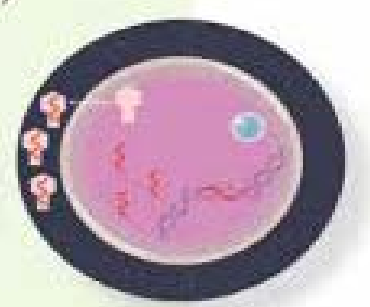

DUPLICATION

Once integrated into the cell's DNA, the virus uses the cell machinery to create more viral proteins and RNA, which assemble on the cell's surface.

\section{TRANSPOSONS (JUMPING GENES)}

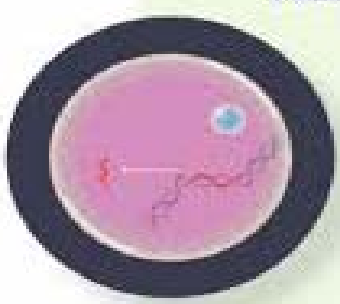

CREATION

Retraviruses embedded in the cell's DNA create viral RNA.

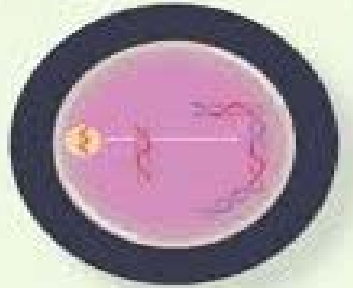

INSERTION

Reverse transcriptase is then used to convert the viral RNA into viral DNA. The viral DNA is inserted somewhere else into the host's ONA.

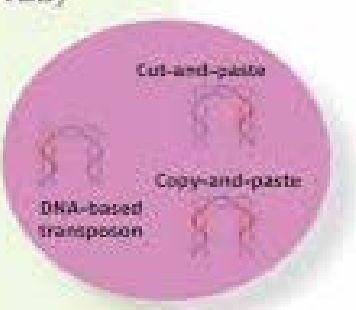

OTHER METHODS

Not all transposans use the RNA copying step, Others can move through the genetic sequence using DNA-based 'cut-and-paste' or 'copy-andpaste' methods.

Figure 2. Evolution of Human viruses [24] 


\section{Chikungunya virus-}

Family- Togaviridae

Genetic structure- Positive sensed single stranded RNA virus.

Body part infected- Muscle and joints.

Spread by- The infection of Chikungunya virus mainly spreads through the bite of the infected mosquito which causes severe joint pain and fever. The infection is travelled from one area to other mainly by infected travellers. Mainly by Aedes egyptii and Aedes albopictus.

\section{Symptoms-}

- Visible symptoms occur mainly between 3-7 days after the biting of infected of infected mosquito.

- Pain in the Joint and high fever is the major symptoms, other symptoms such as headache, swelling and rashes also persist.

- The symptom is mainly risker for the people of the young age group (new born) and older ones (>65 years) although the virus is not deadly but its effect are severe and disabling.

- Major symptoms of chikungunya are similar as Dengue [2] and Zika diseases.

\section{Technique used for detection of virus-}

- Viral isolation and detection by RT-PCR

- Mac ELISA.

Medication required- According to EPA use of registered insect repellent would be very helpful, such as-
- Oil of lemon Eucalyptus
- Para Methane diol
- Zundecanone
- Picaridin
- DEET
- IR3535

The use of some products such as oil of lemon Eucalyptus and Para methane diol is to be avoid on children below 3 years of age. Avoid nearby collection of waters indoor/ Outer door, use AC if available and mosquito net for sleep.

Topographical spread of the virus- (As per Sep 2019 report)

Africa (Angola, Burundi, Benin, Ethiopia, Gabon, Guinea, Kenya. South Africa, Sudan, Uganda, Zimbabwe etc.).

Asia (Bangladesh, Bhutan, China, India, Indonesia, Myanmar, Nepal, Philippines, Saudi Arabia, Sri Lanka, Vietnam, Yemen).

Europe (France, Italy) and many countries of America and Pacific Island.

\section{Influenza virus (A \& B) [15].}

Family- Orthomyxoviridae.
Genetic structure- Negative sense single stranded RNA virus.

Voluntary Muscle inflammation which is characterised by Pain, tenderness, swelling and or weakness is called Myositis. There are several etiologists of Myositis such as diseases of endocrine system, Autoimmune condition, genetic disorder, electrolyte disturbance etc., The infectious agent could be any such as Bacteria, Fungus, Viruses among which the viruses such as Paramyxovirus and enteroviruses are suspected to cause Polymyositis. In which viruses causes diffused muscle involvement with clinical manifestation such as - Acute rhabdomyolysis, Benign acute myositis (Influenza virus), Pleurodynia (Coxsackievirus B), Immune mediated Polymyositis.

Body part infected- Muscles and joints.

Spread by- virus indirectly infects the immune system rather than infecting the muscle directly.

\section{Symptoms-}

- Difficulty in Ambulation along with Muscular pain (in calf).

- Influenza B virus infection mainly involves muscle involvement.

- Major cases have been reported in children of mean 8 years of age which has frequent occurrence in adults.

- The increase in certain chemical compounds such as Aspartate amino transferase, Creatine kinase level, Lactic acid dehydrogenase causes the Myositis which has been revealed by laboratory test.

\section{Technique used for detection of virus-}

- By clinical picture and radiologic imaging.

- Serological testing confirms the etiologic agents.

Medication required- The most effective inhibitor is Neuraminidase but only if it is administered within 36 hours of onset of symptoms of disease.

Topographical spread of the virus - mainly observed in temperate regions known as seasonal disease.

\section{Human Papilloma virus [8].}

Family- Papillomaviridae

Genetic structure- double stranded circular DNA viruses

Body part infected- Anus

Spread by- Anal intercourse with the infected person.

\section{Symptoms-}

- Growth of small warts which is shape of pin head is spotted as the first symptom which later grows in size and covers the entire anal area.

- Most often bleeding, itching, mucus discharge occurs due to the occurrence of Anal warts (Condyloma acuminate) and Anal dysplasia. 
- These warts may develop into cancer if this is not removed on time.

\section{Techniques used for detection of virus-}

- Anoscopy (Anorectal examination).

- Digital rectal examination.

- Speculum examination.

- Anoscopy is done by inserting an instrument which is of about finger size into the area of infection in anus to visualize the warts for the treatment.

\section{Medication required-}

- The risk of the infection can be overcome by the use of condom but will not completely eradicate it.

- A vaccine namely Gardasil (Cervical HPV wart) [11] has been proved to be efficient, for mild warts chemicals such as Podophyllin, trichloroacetic acid, Bichloroacetic acid is used and for the very smaller warts chemicals such as 5 Fluorouracil, imiquimod has been proved to be effective.

- Cryotherapy by using liquid Nitrogen for the recovery of the warts.

\section{Body part infected- external Ear canal [20].}

Spread by- The squamous papilloma is very rare in human ears but is frequently can be seen in the head and neck region. The virus associated with this infection (HPV) causes basically low level of risk in ears so called Benign papilloma.

\section{Symptoms-}

- Singular ulcerated lesions.

- Histological investigation showed the presence of multiple fingers like projections, slender in shape supported by the cores of central fibrovascular covered by Squamous epithelium which is keratinised.

- Mitosis frequently seen in such cells with mild cellular changes.

- Chronic inflammation is also reported.

\section{Techniques used for detection of virus-}

- By detection of Immunohistochemistry.

- In-situ hybridization

- Polymerase chain reaction.

- Southern blot hybridizing.

\section{Medication required-}

- Mostly surgical excision in done.
Carbon dioxide laser used for removal of ear canal papilloma of surface.

Topographical spread of the virus - Latin America and Caribbean, Sub Saharan Africa, Melanesia and south central and South east Asia.

\section{Avian Influenza virus A.}

Family- Orthomyxoviridae.

Genetic structure- RNA virus.

Body part infected- Respiratory system.

Spread by- The bird-flu virus can get into human when it is either inhaled through respiration or virus get into individual's eyes, nose or mouth which is present in the air and environment or due to the unprotected contact with infected birds or the viruses present on the surfaces, these infections could be mild or severe.

\section{Symptoms-}

- Common symptoms being fever, cough, sore throat, conjunctivitis followed by abdominal pain, nausea, diarrhoea and vomiting sometimes.

- Cause severe respiratory illness.

\section{Techniques used for the detection of virus-}

- Laboratory testing of the swab taken from upper respiratory tract for the detection of mild infection.

- For the detection of severe infection, the swab from lower respiratory tract is also along with upper respiratory tract swab.

\section{Medication required-}

\section{- Oseltamivir \\ - Peramivir \\ - Zanamivir \\ - Stockpiled vaccine}

Topographical spread of the virus - In different part of Asia, Europe, Africa, and middle east.

\section{Human Rhinoviruses (HRV) [19].}

Family- Picornaviridae.

Genetic structure- Positive sense single stranded RNA virus. Several kinds of chronic pulmonary diseases, Asthma development, some severe bronchiolitis in the children's and the infants are linked to HRV.

Body part infected- Nasal area.

Spread by- Person to person via contact or aerosol mainly through intranasal or conjunctival inoculation.

\section{Symptoms-}

- Generally reported in children $\mathrm{n}$ with certain mild or Asymptomatic infections. 
- It has been reported that within 2-10 hours of infection soar or scratchy throat nasal irritation is felt, common symptoms being subjective fever, congestion and malaise.

- Rhinosinusitis

- Lower respiratory infection/ croup, Bronchiolitis, community acquired pneumonia.

- Asthma, Cystic fibrosis.

\section{Techniques used for the detection of virus-}

- RT-PCR (molecular detection method)

- Middle ear fluid specimen.

- Computed tomography

- MRI

- ELISA

\section{Medication required-}

- Maintaining safe distance between individuals \& uses of respiratory masks.

- Hand hygiene

- No proper vaccine.

Topographical spread of the virus - Throughout the world such as temperate, tropical, subtropical countries (whole year), the high peak of the infection is seen in temperate climate with low peak in spring. Table 1: describes certain kind of viruses over time specially in the oral cavity targeting mostly mucoepithelial cells and B-cells.

\section{SARS-COV-2 (2019) [13].}

Family- $\beta$ coronavirus family. Similar to viral pneumonia.

Genetic structure- Single stranded RNA virus diameter being $80 \mathrm{~nm}-120 \mathrm{~nm}$.
Natural host- Bats.

Spread by- Droplets and close contact along with the aerosol transmission with the infected person, the stools, GI tract, saliva, tract also detected by tears and conjunctival secretions of patients.

\section{Symptoms-}

- Large studies have reported that this virus mainly effects the patient of age above 65 (old aged people) with weak or low immune level, also people with diabetes, hypertension and heart disease are more susceptible to the virus.

- Symptoms are mainly reported between 3-14 days of infection.

- Most common symptoms being fever, cough, fatigue, diarrhoea, vomiting with many acute respiratory distress syndromes.

- The oxygenation index is lowered while in effect of this virus.

\section{Techniques used for detection of virus-}

- qRT-PCR

- Nucleocapsid detection

- Capture ELISA

- Nanopore target sequencing

- Antibody based immunoassay sequencing.

\section{Medication required-}

- Remdesivir (Xiao et.al), Chloroquinone, Arbidol.

- Immunoenhancement therapy.

- Auxiliary blood purification treatment.

Topographical spread of the virus - All over the world, the most affected countries are china, America, India.

Table 1. Pathogenic viruses mostly present in the oral cavity and relevant antiviral compounds [3].

\begin{tabular}{|c|c|c|c|c|}
\hline Serial no. & Type & Target & Oral manifestation & Other pathology \\
\hline 1 & HSV-1 & Mucoepithelial & Herpes ulcers & Genital ulcers \\
\hline 2 & HSV-2 & Mucoepithelial & Herpes ulcers & Genital ulcers \\
\hline 3 & VZV & Mucoepithelial & $\begin{array}{l}\text { Possible oral manifestations of } \\
\text { Chicken pox and Herpes } \\
\text { zoster. }\end{array}$ & $\begin{array}{l}\text { Chicken pox and herpes } \\
\text { zoster }\end{array}$ \\
\hline 4 & EVB & B-cells and epithelial cells & $\begin{array}{l}\text { Hairy leukoplakia, Periodontis } \\
\text { (nasopharyngeal carcinoma). }\end{array}$ & $\begin{array}{l}\text { Mononucleosis and } \\
\text { Lymphoma }\end{array}$ \\
\hline 5 & HCMV & $\begin{array}{l}\text { Monocytes, Lymphocytes and } \\
\text { epithelial cells. }\end{array}$ & Periodontitis & - \\
\hline 6 & HHV-6 & Monocytes and Macrophages & - & Roseola in infants. \\
\hline 7 & HHV-7 & T-cells and possibly others. & - & Roseola in infants. \\
\hline 8 & KSHV & B-cells and possibly others. & - & $\begin{array}{c}\text { Kaposi sarcoma (in AIDS } \\
\text { patients). }\end{array}$ \\
\hline
\end{tabular}




\section{Reproductive System virus [21], [1], [16], [18].}

Genetic structure- either RNA/DNA.

Human reproductive system is the most complicated part of the body either of male or female. It can be considered as the most sensitive part of the human body which consist of numerous of microbes residing that could either beneficial or harmful. Some of the diseases of the human genital system are Human immunodeficiency virus, Cytomegalovirus, Epstein Barr virus, Papillomavirus, Hepatitis virus, Adenovirus/ Herpesvirus.

These viruses mainly infect the CD4 cell of Immune system.

Spread by- Certain kind of body liquids such as Blood, semen, anal fluids, vaginal discharge or secretion, Breast milk and certain kind of sexual contact with the infected person by fluid transmission. Fig 3- describes the transformation of Epstein virus including its proliferation, lytic cycle, infection then transformation etc.

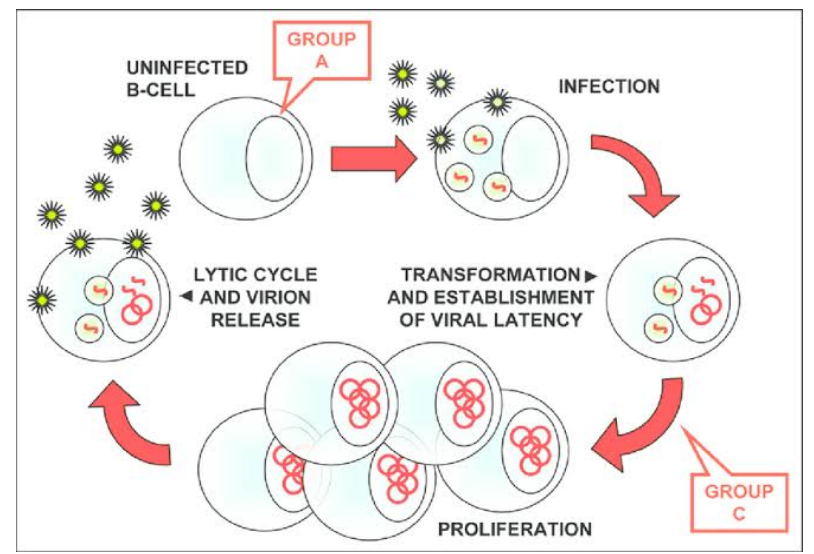

Figure 3. Transformation \& establishment of Epstein Barr viruses [25]

\section{Symptoms-}

- Major symptoms of the infecting virus are not observable easily over many years but in few people (nearly 70\%) develop the symptoms of Flu i.e. Acute retroviral symptoms within few weeks of virus attacking the body (nearly within 2-6 weeks)

- Common symptoms for the person infected with such viruses are fever, sore throat, tiredness, weight loss.

- Last stage symptoms being diarrhoea, dry cough, permanent tiredness, unintentional weight loss etc.

- Along with the Flu certain neurological impairment and fatal encephalomyelitis is also reported in certain cases of people.

- Infection in the new infants in inherited from the pregnant mother who is infected.

- These kinds of viruses mainly affect the people with low immune response such as those which have undergone organ, bone marrow or stem cell transplant.

- Baby infected with such viruses have premature birth, enlarged liver and low birth weight.

\section{Techniques for the detection of the viruses-}

- Electron microscopy, Immunochemistry, In situ-PCR

- ELISA test, Home test, Saliva test, Viral load test, Western blot.

- Serological PCR, CSF test.

- Prenatal test for detection of viral infection in baby is done by testing Amniocentesis, while pregnancy.

Medication required- certain kinds of drugs such as Acyclovir, Valacyclovir and Famciclovir are given to the infected person in different dosages.

Topographical spread of the virus - All over the world in many forms. Table 2 demonstrates some of the most common viruses of the genital part specially found in Humans.

Table 2. Some very common viruses of human genital part [10]

\begin{tabular}{|c|c|c|c|c|c|}
\hline Diseases & Pathogen & Symptoms & Mode of transmission & Diagnostic tests & $\begin{array}{c}\text { Vaccines or } \\
\text { antimicrobial drugs }\end{array}$ \\
\hline $\begin{array}{c}\text { Cancer of } \\
\text { Cervix }\end{array}$ & HPV 16, 18 & $\begin{array}{c}\text { Irregular growth of the cells in } \\
\text { cervix area. }\end{array}$ & $\begin{array}{c}\text { Direct sexual contact with } \\
\text { the infected person. }\end{array}$ & Smear of Pap. & $\begin{array}{c}\text { Cervarix vaccine. } \\
\text { Gardasil vaccine. }\end{array}$ \\
\hline $\begin{array}{c}\text { Genital area } \\
\text { Herpes }\end{array}$ & $\begin{array}{c}\text { Herpes } \\
\text { simplex } \\
\text { virus } 1 / 2\end{array}$ & $\begin{array}{c}\text { Asymptomatic in many cases. } \\
\text { Genital area covered with } \\
\text { outbreak of skin vesicles. }\end{array}$ & $\begin{array}{c}\text { Contact with open lesion } \\
\text { or body fluid transmission } \\
\text { from the infected person. }\end{array}$ & $\begin{array}{c}\text { Culture if the } \\
\text { virus in-vivo, } \\
\text { PCR, ELISA. }\end{array}$ & $\begin{array}{c}\text { Acyclovir, } \\
\text { Famciclovir, } \\
\text { Valacyclovir }\end{array}$ \\
\hline $\begin{array}{c}\text { Papilloma of } \\
\text { Human }\end{array}$ & $\begin{array}{c}\text { Human } \\
\text { Papilloma } \\
\text { virus (HPV) }\end{array}$ & $\begin{array}{c}\text { Warts in different areas } \\
\text { specially in genital area. }\end{array}$ & $\begin{array}{c}\text { Sexual contact, fluid } \\
\text { transmission }\end{array}$ & Smear of Pap & $\begin{array}{c}\text { Imiquimod, Sine } \\
\text { catechins, podofilox. }\end{array}$ \\
\hline $\begin{array}{c}\text { Neonatal } \\
\text { herpes }\end{array}$ & $\begin{array}{c}\text { Herpes } \\
\text { simplex } \\
\text { virus } 1 / 2\end{array}$ & $\begin{array}{c}\text { Mortality in foetus or new } \\
\text { born, } \\
\text { Motor impairment, } \\
\text { Mucous membrane of eyes } \\
\text { and skin has small vesicles, } \\
\text { disseminated infections. }\end{array}$ & $\begin{array}{c}\text { Transplacental infection is } \\
\text { observed in some cases, or } \\
\text { due to the exposure of } \\
\text { virus by the birth canal. }\end{array}$ & $\begin{array}{c}\text { PCR and viral } \\
\text { culture. }\end{array}$ & Acyclovir. \\
\hline
\end{tabular}




\section{Conclusions}

There are many numbers of viruses that have infected the body of human in one or the other way and the consequence of these viral infection have been extremely serious in every aspect of life causing several kinds of risk either its organ integrity, disease development or suppression of immune response and certain kinds of changes in endocrine and reproductive system. These are few examples of body infections which are very common to the body and have been much studied in our past and many of these infection debates are still being carried out continuously overtime as no proper vaccine or medication has been developed to cure it. But attention is needed on such viruses which are evolving to be more dangerous with the time and causing risk to life. These viruses need a superficial attention in the relative paucity to the data concerning the endocrine and immune system.

If we keep in mind both economic and health reasons of modern human, it is very urgent requirement to develop certain techniques and tools to study these viruses in a more optimistic way so that we must be ready to overcome their effect if they evolve again in near future with new tendency to attack our body and immune, we must be ready for the reservoir of the virus too. Few more antiviral therapies should be developed to prevent the infection of such kind of microbes.

The development of new treatment strategies of virus in order to eradicate them and also to overcome the virus induced dysfunction on immune system needs much progress and attention.

\section{Acknowledgements}

I gratefully acknowledge to the people who have supported me in my work by providing me the source of information, Head of Department Prof Pooja Singh and My Supervisor Dr. Deepa Srivastava for helping me in bringing out my work.

\section{REFERENCES}

[1] Allahverdiyev N., Duran M., Ozguven S., Koltas, “Antiviral activity of the volatile oils of Melissa officinalis L. against Herpes simplex virus type-2," Phytomedicine, vol. 11, pp. 657-661, 2004.

[2] Chu C. -B., \& Yang C.-C, "Dengue associated telogen effluvium. A report of 14 patients,” Dermatol. Sin, Vol. 35, pp. 124-126, 2017.

[3] Daisuke A., \& Nakashima H, "Pathogenic viruses commonly present in the oral cavity and relevant antiviral compounds derived from natural products,” Medicines (Basal), vol. 5no. 4, 120, 2018.
[4] Flipse J., Diosa- Toro M.A., Van Der Ende- Metselaar H., Herrera- Rodriguez J., Urcuqui- Inchuma S., et al., "Dengue tropism for macrophages and dendritic cells: the host cell effect,” J. Gen. Virol, Vol 97, pp. 1531-1536. 2016b

[5] http://www.cdc.gov/std/tg2015/herpes.htm.

[6] International committee on taxonomy of viruses. (2010).

[7] Kai-che Wei., Mei-shu Huang \& Tsung- Hsien Chang, "Dengue virus infects primary human hair follicle dermal papilla cells," Frontiers in cellular and infection microbiology, vol. 8, pp. 268, 2018.

[8] Kapoor A., et al. "A newly identified bacovirus species in human stool,” J. Infect. Dis, vol. 199, pp. 196-200, 2008.

[9] Kimberly et al., "Centers for disease control and prevention," Sexually transmitted diseases treatment guidelines: Genital Herpes, 2015.

[10] Laiskonis A., Thune T., Neldam S., Hiltunenback E, "Valacyclovir in the treatment of facial herpes simplex virus infection,” J Infect Dis, vol. 186, no.1, pp. S66-S70, 2002.

[11] Lauren T., \& Alan G., Waxman, “Cervical cancer prevention: Immunization and screening," Medical Clinics of North America, vol. 99, no. 3, pp.469-477, 2015.

[12] Levine A. J., Enquist I. W, “History of virology,” In fields virology 5th edition Phildelphia, PA: Lippincott Williams and wilkins, pp. 565-604, 2007.

[13] L. wang., \& Qingquan Liu, "Review of the 2019 novel coronavirus (SARS-CoV-2) based on current evidence," International Journal of Antimicrobial Agents, vol. 55, no. 6, 2020.

[14] Mark woolhouse., Fiona scott., \& Margo chase-Topping, "Human viruses: discovery and emergence. Philosophical transaction B,” The Royal Society Publishing, vol. 367, no. 1604, pp. 2864-2871, 2012.

[15] Nancy F., Crum- Cianflone, "Bacterial, Fungal, Parasitic and viral Myositis,” Clinical Microbiology Reviews, vol. 21, no. 3, pp. 473-494, 2008.

[16] Nathalie D., and Bernard J, "Viruses in the Mammalian Male genital tract and their effects on the Reproductive system," Microbiology and Molecular Biology Reviews, vol. 65, no. 2, pp. 208-231, 2001.

[17] Jadhav P., Kapoor N., Thomas Hingorani lal B., \& Kshirsagar N, "Antiviral potential of selected Indian Medicinal plants against Herpes simplex virus 1 and 2,” North American Journal of Medical sciences, vol. 4 no. 12, pp. 641-647, 2012.

[18] Pornchai Sathirapanya, "Isolated and bilateral simultaneous facial palsy disclosing early human immunodeficiency virus infection,” Singapore Medical Journal, vol. 56, no. 6, pp. 105-106, 2015.

[19] Samantha E. Jacobs., Daryl M. Lamson., Thomas J. waish, "Human Rhinoviruses. American society for microbiology," clinical Microbiology reviews, vol. 26, no. 1, pp. 135-162, 2013.

[20] Shuyi wang., Herman Yee., Beverly Y. wang, "Papillomas of the External Ear Canal: Report of ten cases in chinese patient with HPV insitu Hybridization,” Springer: Head and neck 
pathology, vol. 3, no. 3, pp. 207-211, 2009.

[21] Ruiz LM., \& Kirmani B, "Presentation of Bilateral peripheral seventh cranical Nerve palsy in an HIV Patient,” Case Rep Neurol Med, 2012.

[22] Wolfe N. D., Dunavan C. P., Diamond J, “Origins of major human infectious diseases,” Nature, vol. 447, pp. 279-283, 2007.
[23] WWW.ictvdb.org/Ictv/ICTVdBsearcg.htm.

[24] http://www.sciencefocus.com/the-human-body/virus-human -evolution/amp.

[25] Godshalk S., Mcintosh S,B., Slack F, "Epstein Barr virus mediated dysregulation of human microRNA expression," Cell Cycle, vol. 7, no. 23, pp. 3595-3600, 2008. 